УДК 37.013.42.062.09:82-051І.Франко

МИХАЙЛО МАТКОВСЬКИЙ, кандидат філософських наук, асистент кафедри загальної педагогіки та педагогіки вищої школи, Львівський начіональний університету імені Івана Франка, Україна ORCID ID 0000-0002-5846-4719 Matkovskyi2017r@gmail.com

\title{
ФРАНКІВСЬКА КОНЦЕПЦІЯ РОЛІ ТА МІСЦЯ СОЦАЛЬНИХ ІНСТИТУТІВ У СТАНОВЛЕННІ ОСОБИСТОСТІ: КОНТЕКСТ СУЧАСНИХ ВИКЛИКІВ
}

MYKHAILO MATKOVSKYI, PhD in Education, assistant of the department of General Pedagogy and Pedagogy of Higher

Education of Ivan Franko National University of Lviv, Ukraine

\section{FRANKO'S CONCEPT OF THE ROLE AND PLACE OF SOCIAL INSTITUTIONS IN PERSONAL DETERMINATION: THE CONTEXT OF CONTEMPORARY CHALLENGES}

\begin{abstract}
У статті досліджуються погляди Івана Франка на роль соціальних інститутів у процесі формування молоді. Обгрунтовується необхідність пошуку нових стратегій та вдосконалення наявних щодо підтримки процесів соціалізації, адаптації і самореалізації молоді в соціумі, а також важливості залучення до цих процесів досвіду видатних мислителів минулого, зокрема Івана Франка. Доводиться важливість реформування соціальних інститутів суспільства як головних форпостів формування освітнього простору. Аргументується актуальність упровадження педагогічних ідей Івана Франка у процес навчання, виховання і розвитку особистості.
\end{abstract}

Ключові слова: освітній простір, Іван Франко, соціальний інститут, становлення молоді, особистість.

Ivan Franko's views on the role of social institutions in the process of youth formation are explored. The necessity of finding new strategies and improvement of the existing ones in support of the processes of socialization, adaptation and selfrealization of young people in the society, as well as the importance of

(C) М. Матковський involving in these processes the experience of prominent thinkers of the past, in particular Ivan Franko are substantiated. The importance of reforming the social institutions of society as the main outposts of the formation of educational space is proved. The urgency of introducing Ivan Franko's pedagogical ideas into the process of education, upbringing and personal development is argued.

Key words: educational space, Ivan Franko, social institute, youth formation, personality.

Мета: здійснити концептуалізація ідей Івана Франка щодо місця і ролі соціальних інститутів в контексті становлення української молоді.

Постановка проблеми в загальному вигляді. Для сучасного суспільства життєво важливим є закріплення та гармонізація певних типів соціальної взаємодії, а також створення відповідних умов, у контексті яких молодь, як майбутнє суспільства, могла б повноцінно формуватися на всіх життєвих етапах. Досягненню цієї мети сприяють такі суспільні елементи, як соціальні інститути, головне завдання яких забезпечувати належну стійкість та відтворення суспільства. У сучасному українському суспільстві простежуємо типові риси інституційної кризи, що полягає в дисфункції діяльності основних соціальних інститутів. Однією з її причин є перебіг складних трансформаційних процесів, що відбуваються в Україні та загалом у світі, а також динамізм розвитку сучасної цивілізації. Нездатність соціальних інститутів стабілізувати суспільне життя, низька довіра суспільства до державних інституцій вимагають від соціуму нагального переосмислення та реформування інституційної гілки суспільного життя.

Соціальні інститути як механізми соціальної взаємодії та відтворення формувалися впродовж тривалого часу і як категорії історичні потребують історико-теоретичного аналізу. Значну увагу цій проблемі приділяли видатні українські мислителі кінця XIX - початку XX ст., зокрема й Іван Франко.

На жаль погляди Івана Франка в контексті педагогічних проблем в науковій літературі $є$ ще не до кінця осмисленими та потребують додаткових наукових досліджень.

Аналіз останніх досліджень i публікацій. Дослідженнями соціально-педагогічних та соціальнопсихологічних аспектів становлення особистості займалися I. Надольний, Г. Андреєва, I. Кон, М. Лукашевич, О. Мудрик, А. Петровський, О. Вишневський, С. Оле- 
нич та інші. Соціально-філософський та філософсько-антропологічний аналіз молодіжної проблематики щодо розвитку та становлення особистості здійснено у працях В. Андрущенка, В. Беха, Л. Губерського, А. Ручки, В. Скотного, Н. Скотної та інші. Моральноетичні аспекти Франкової людинознавчої спадщини досліджували А. Пашук, Н. Гобач, Е. Соловей, Б. Тихолоз, У. Хамар, Н. Дорошенко та інші. Педагогічні ідеї та погляди Івана Франка знайшли своє відображення відображено в працях О. Дзеверіна, Т. Біленко, Г. Васяновича, Р Вишнівського, В. Луців та інші.

Виклад основного матеріалу дослідження. Засадничим суспільним інститутом, рівно ж як і визначальним осередком формування моральних засад та переконань особистості, є сім'я. Останні десятиліття в сучасному суспільстві спостерігаємо тенденцію занепаду традиційних моральних норм та цінностей, що тягне за собою шлейф негативних наслідків. Перебуваючи в тісному взаємозв'язку iз суспільством та виступаючи його невід'ємною складовою, сім'я дуже чутливо реагує на будь-які зміни, що відбуваються в соціумі, та потрапляє в поле їхньої дії. Цей процес зворотний. Відтак конче назріла потреба по новому переосмислити моральні засади виховання в сім'ї в контексті сучасних викликів. Вельми важливими та корисними в контексті окресленої проблеми є міркування та поради Івана Франка. Мислитель доводив, що підвалини моральності її соціальної активності закладаються в сімейному середовищі в дошкільний період. На його думку, найважливішим є вплив батьків на дитину в ранньому віці. Родинне виховання має грунтуватися на національному єстві, народній педагогіці, житті народу і його традиціях, мусить вирости з його культурного стану, інакше це буде, на думку I. Франка, марна трата часу і сил. Важливо сприяти прагненню дітей до пізнання природи й життя. Виховання всебічно розвинутого покоління, переконаний I. Франко, можливе завдяки боротьбі з реальними життєвими труднощами, де очі дітей не повинні бути закриті на протилежні аргументи та докази. У своїх творах Франко часто описував проблемні ситуації, що виникали в тогочасних сім'ях. Багато 3 них мають автобіографічний характер. Зображуючи їх, письменник намагався розкрити перед суспільним загалом весь той негативізм, який несуть певні проблеми і для дитини, і для суспільства загалом. Яскравим прикладом $\epsilon$ оповідання "Малий Мирон". Цитуємо: "А вже найбільша була біда Миронові з тим мисленням! Не вмів мислити, та й годі. Що тільки, бувало, скаже, все якесь не таке, як треба, все мати або хто-будь другий каже йому: Та чому ти, тумане вісімнацятий, не помислиш уперед, що маєш казати, а так бовтаєш, як той рибак бовтом бовтає! I що вже бідний Мирон не намучився, щоб вимислити, а потім сказати щось розумного, - ні, не можна, та й годі. Бідний Мирон прийшов до того переконання, що він не вміє мислити!" (Франко, 1978, c. 70). Постійна критика з боку мами і сусідів, наголошування на тому, що він не вміє "мислити як люди", вельми негативно впливали на дитину. Художнє зображення аналогічних проблемних ситуацій має на нашу думку, допомагати батькам у формуванні соціальної та моральної відповідальності за виховання дітей, а також активізувати суспільну увагу до проблемних сімей. "Свідоме батьківство передбачає глибоке розуміння своїх можливостей та обов'язків у формуванні цілісної особистості дитини як власної відповідальності перед людством" (Бєлєнька, Богініч \& Машовеиь, 2006, с. 203). Різноаспектно аналізуючи твори письменника, доходимо висновку, що фундаментальними засадами, на яких має базуватися виховання в родині, на думку Франка, повинні бути принципи гуманізму, всебічного розвитку, трудового виховання, вироблення здатності до самостійного творчого мислення, удосконалення моральних якостей і способу життя тощо. Традиційна українська родина, доводив Франко, повинна стати головним осередком формування духовно-моральних та національних цінностей, патріотизму, місцем прищеплення здорових норм і навичок поведінки, пошани до рідної мови, народних звичаїв і традицій тощо. Гуманістичні ідеї Івана Франка, зокрема щодо вихо- вання в сім'ї, суголосні з тими завданнями, які стоять і перед сучасним українським суспільством.

Важливим суспільним та державним інститутом, вплив якого $\epsilon$ надзвичайно вагомий для становлення особистості, є інститут освіти. Освіта є визначальним агентом "становлення громадянського суспільства, і громадянське суспільство для освіти є соціокультурним феноменом удосконалення всіх сфер суспільного виробництва, а головне - всебічного та цілісного формування людини не лише як головної складової продуктивних сил, а мети суспільних перетворень в інтересах самої людини" (Haдольний, 2011, с. 281).

Зі здобуттям власної незалежності перед нашою державою постало чимало суспільних викликів та проблем, вирішити які неможливо без кардинальних змін та реформ у сфері освіти. "Потреба глибинної перебудови освіти $є$ об'єктивною необхідністю, що диктується процесами трансформації нашого суспільства", - узагальнює відомий педагог, науковець та популяризатор Франкової гуманістики Омелян Вишневський (Вишневський, 2006, с. 45).

Дослідженню проблем освіти та пошукам шляхів їх розв'язання велику увагу приділяв I. Франко. Це вилилося в написання багатьох статей та художніх творів: "Наші народні школи та їх потреби", "Середні школи в Галичині в 1875-1883 pp.", "Малий Мирон" "Борис Граб", "Отець-гуморист", "Учитель", "Оловець", "Die Schonschreiben", "Грицева шкільна наука" тощо. У цих творах письменник правдиво й художньо переконливо описує стан тодішньої освіти, низький рівень педагогічної підготовки більшості вчителів, сміливо оголює всі недоліки тогочасного навчально-виховного процесу і водночас акцентує на важливості школи та особи вчителя як головного інструменту в навчанні, вихованні та розвитку молоді. Багато освітніх проблем, які намагається всебічно і в різному форматі осмислити I. Франко, актуальні й досі. Це надає його концептуальним ідеям щодо проблем освіти та становлення особистості певного універсалізму й позавимірності.

Одним 3 найважливіших дер- 
жавних завдань освітнього характеру, на думку Франка, має бути створення відповідних умов для всебічної самореалізації особистості, задоволення освітніх потреб і запитів суспільства. Проблема низької освіченості в суспільстві автоматично породжує колосальну кількість проблем особистісного та загальнодержавного характеpy. "Темний чоловік, пише мислитель, не може дати собі ради ні в чім, не може докопатися правди в тім, що йому говорять.... Темного чоловіка кожний одурить і залякає, він не може ніколи бути певний, в чім його право і обов'язок" (Дзеверін, 1960, с. 58). На думку, В. Андрущенка, вирішити цю проблему, допоможе залучення європейського освітнього досвіду. Оскільки "європейська освіта - поступове вирівнювання можливостей у доступі до вищої освіти кожного, незалежно від місця проживання, етнонаціонального походження, конфесійної належності, майнового стану батьків та інших обставин" (Андрущенко, 2011, с. 8). Науковець наголошує "всі діти однакові. Усі талановиті. Усі прагнуть бути великими і знаменитими" (Андрущзенко, 2011, с. 8).

Сучасний світ переживає глобальну кризу освіти. Чимало галузей так швидко розвиваються, що сучасна освіта не встигає оновлювати знання та методику в навчальному процесі. Половина всіх знань, отриманих студентами в університеті, за кілька років "старіють" та знецінюються, що, своєю чергою, спричинює непрофесійність працівника. Іван Франко передбачив загострення цієї проблеми та дав чимало змістовних порад щодо її розв'язання. Головне завдання освіти, на думку мислителя, - це розвинути в людини здатність та навички до безперебійного навчання та вдосконалення протягом всього життя, здатність до самостійного творчого мислення. "Власна думка! Власна духовна праця, ось у чім властива ціль гімназії!" - повторював він не раз. Знання після закінчення навчання частково загубляться, але здатність мислити, володіти своїм "мізком" залишиться, - неодноразово підкреслював він (Франко, 1978, с. 178). Становлення особистості, наголошує Н. Скотна, це найперше ії самоактивність. I виховання дієвим може по-справ- жньому бути тільки тоді, коли переходить у самовиховання (Скотна, 2005, с. 164).

Глибокі рефлексії над тим, які головні завдання повинні стояти перед освітою, знаходимо в повісті Івана Франка "Перехресні стежки": "Освіта ... Що таке освіта? Чи вмілість читати і писати - се освіта? Чи, прочитавши всі книжечки "Просвіти" і "Общества Качковського", чоловік зробиться освіченим? Що більше, чи, скінчивши університет і одержавши диплом, чоловік робиться освіченим? Так освіченим, щоб у кождій життєвій пригоді міг собі дати раду? Щоб не робив дурниць у найближчих йому, найпрактичніших справах? $<$... Н Нi, книжкова освіта ще не дає життєвої освіти. Неписьменний торговець може бути в життєвих справах освіченішим чоловіком від доктора філософії. Життєва освіта, ось в чім річ! Щоб чоловік привикав жити з людьми, порозуміватися 3 ними, солідаризуватися. Почуття солідарності між людьми се мета ... школи" (Франко, 1979, c. 251). Власне тут І. Франко дає універсальні поради, як подолати глобальну особистісну та суспільно-гуманітарну кризу.

Надзвичайно важливим суспільним інститутом є релігійні організації. Найпоширенішою організаційною формою релігії в суспільстві є церква. Цей суспільний інститут $є$ вагомим фактором суспільного життя та його стабільності, а також його духовного зростання.

Розглядаючи вплив релігії на розвиток людства, мислитель переконливо доводить, що релігія, особливо християнство, є органічним чинником формування культури народів, та духовно-моральних критеріїв людства. Релігійні уявлення виникають у людини найперше з їі внутрішньої сутності, вважав науковець, виходять 3 їі духовних потреб. Звернення мислителя до релігійної тематики було не випадковим. Юний Франко виховувався в родині, де ревно шанували християнські цінності, а також вчився в школі отців-василіян у Дрогобичі.

Усвідомлюючи вагу та винятковість ролі церкви як основної організаційної форми релігії у суспільному житті, мислитель приділяв іiі проблемам велику увагу. Предметом його критики були церковні діячі та їхня діяльність. Критичні зауваження мислителя були цілком обгрунтованими, і 3 багатьма із них погоджувався, як ми вже згадували митрополит А. Шептицький. I. Франко також порушував важливі питання філософськорелігійного характеру, які безпосередньо торкалися духовних підвалин релігії і справді потребували дискусії та переосмислення.

Коли розпадається релігія, доводив Франко, "ніхто вже не вірить в існування божого провидіння i справедливості, немовби розсипається моральна база суспільства, знищується кістяк його життя" (Франко, 1986, с. 14). Тут ми можемо провести аналогію 3 "категоричним імперативом" I. Канта, який вважає віру в Бога гарантом i взірцем моральної поведінки. I. Франко, як і знаменитий німецький філософ, вважає, що люди повинні "бути чесними не під впливом кари й нагороди, а заради самого добра" (Франко, 1986, с. 15).

Одним з основних соціальних інститутів суспільства $є$ інститут економіки. Він забезпечує регулювання трудових взаємин у суспільстві. Трудові відносини визначають місце людини в соціумі, закріплюють їі соціальні зв'язки, визначають характер її взаємодії із суспільством.

Згаданий соціальний інститут перебуває в постійному розвитку та реструктуризації. Перманентним є також процес інституалізації економічних поглядів, який полягає в переоцінці та утворенні інших трудових цінностей, появі модерних економічних ролей i норм поведінки та якостей працівників. За останні десятиліття в українському суспільстві відбулися зміни в світоглядних уявленнях та ціннісних орієнтаціях. Науково-технічний прогрес, автоматизація та комп'ютеризація виробництва, зниження ролі й частки продуктивної праці, розширення сфер дозвілля й споживання змінило саме розуміння праці, ставлення людини до неї, трансформувало зміст праці та її роль в житті людини й суспільства.

Соціальний інститут економіки має складну структуру. Його можна розглядати як сукупність більш конкретних інститутів. Одним з найважливіших серед них $\epsilon$ інститут праці, який, на думку Івана Фран- 
ка, дуже тісно пов'язаний зі становленням особистості. Тема праці та трудова мораль посідали вагоме місце в колі зацікавлень та гуманітарних пріоритетів Івана Франка. Мислитель наголошував, що особливо важливим й актуальним у вихованні молоді $є$ виховання творчої працьовитості, її високої моральності та усвідомлення соціальної значущості праці як обов'язку й духовної потреби, почуття особистої відповідальності та значущості в розбудові держави. Духовне ледарство, - то злочин проти гуманності, - стверджував він. Франкові поради та концептуальні ідеї щодо ролі праці в житті людини особливо актуалізувалися в нашому постіндустріальному суспільстві. Свої думки, що стосуються означеної проблеми, мислитель висвітлював у низці статей, а також в поезії та прозі. Маємо на увазі статті "Наука і її взаємини 3 працюючими класами", "Наші народні школи та їх потреби", "Мислі о еволюції в історії людськості", оповідання "Борис Граб", "У кузні", поезію "Пісня і праця" та в низку інших творів. Дослідження цих творів дає нам підстави стверджувати, що у вихованні та становленні особистості мислитель надавав вагомого значення саме вихованню через трудову діяльність.

Аналізуючи філософський світогляд мислителя, А. Пашук зауважував спорідненість ідей Франка та Сковороди в питаннях сенсу та вагомості категорії праці. Ідеї Франка постають як модифікована та осучаснена концепція "спорідненої праці", яка "веде у світ реалізації до радости, свободи, щастя" (Пащук, 2007, с. 31). Н. Горбач доходить висновку, що суспільно корисну працю Іван Франко вважав найважливішою суспільною категорією, без якої неможливий суспільний прогрес (Пащук, 2007, c. 64). Аксіоматично, саме в процесі праці нагромаджуються матеріальні та духовні цінності, через працю людство досягає свого розвитку.

Праця як підгрунтя суспільного життя виконує надзвичайно важливу роль у розвитку та вихованні людини, а також у формуванні їі світогляду. Праця розкриває істинну суть людини, а через творчу діяльність відкриває всі їі задатки та здібності. Звеличення праці, - зауважує Н. Дорошенко, яскраво виражено і в моральному кодексі Франка, для якого питання моралі було предметом постійної уваги (Дорошенко, 1953, с. 86).

Повсякденна суспільна праця, спрямована на вирішення важливих суспільних проблем, на думку I. Франка, є сенсом життя та моральним імперативом, а також "єдиною основою людського щастя і добробуту" (Франко, 1978, с. 39).

Прикметно, що під працею I. Франко розуміє не тільки фізичну чи розумову, а й духовну, яка виявляється через самовдосконалення особистості. Він наголошує, що "життя без діяльності, без думки, без боротьби " шкідливе для молодої людини. Праця є ліком-панацеєю від усіх духовних недуг людини й соціуму, єдино можливим та гідним людини способом існування, найважливішою чеснотою. Праця - єдина служба людям, народові, загальнолюдським ідеалам. Вона постає основою суспільного життя, відіграє головну роль у розвитку та вихованні людини, формуванні їі світогляду й характеру. Саме в діяльності формуються найважливіші риси особистості, вольові якості, іiі розум, увага, уява, пам'ять, емоційна сфера тощо. Тому надзвичайно важливим $\epsilon$ виховання працелюбності, а особливу увагу цьому мають приділяти такі соціальні інститути, як сім'я та школа. "Виховання, - наголошував педагог, - повинно бути справою народною... аби запобігти створенню штучної нерівності між людьми і дати кожному можливість усебічного розвитку своїх природних сил на користь суспільства, виховання повинно бути поставлене так, щоб по можливості кожний залишався робітником одночасно фізичної i розумової праці. Нинішню однобічну систему виховання повинно замінити виховання всебічне" (Франко, 1986, с. 452).

У цінності праці Франко не має ані меншого сумніву. Саме працелюбність, вважав мислитель, є однією $з$ найважливіших засад формування людської гідності.

Надзвичайно плідною та корисною є спільна праця. Бездіяльність Франко називає "іржею", яка роз'їдає міць людей, тоді як спільна ж праця зміцнює стосунки між ними, гартує їх. В оповіданні "У кузні"
Франко так описує свої дитячі спогади: "I певно, в ту пору ніхто з них не думав, що та кузня, і та компанія в ній, і той іiї дружній радісний настрій лишаться живим і незатертими в душі маленького рудоволосого хлопчини, що босий, в одній сорочці сидів в куті коло огнища, i якого дбайливий батько чає від часу просив відступити від скачучих іскор" (Франко, 1979, с. $169-$ 170). Також важливість і корисність спільної праці та боротьби, яку об'єднує спільна мета, Франко описав в історичній повісті "Захар Беркут". "Батьки і браття! Нинішня наша побіда - велике діло для нас. Чим ми побідили? Чи нашим оружиєм тілько? Ні. Чи нашою хитрістю тільки? Ні. Ми побідили нашим громадським ладом, нашою згодою і дружністю. Уважайте добpe на се! Доки будете жити в громадськім порядку, дружно держатися купи, незломно стояти всі за одного, в один за всіх, доти ніяка ворожа сила не побідить вас" (Франко, 1979, с. 153-154).

Висновки та перспективи подальших досліджень. Перелік розглянутих соціальних інститутів не $\epsilon$ вичерпним. Для повного висвітлення ця тематика потребує спеціального дослідження. У статті розглянуто ті соціальні інститути, які, на нашу думку, найвагоміші в суспільстві та яким приділяв увагу Іван Франко.

Молодь у сучасному суспільстві перебуває в постійному розвитку, а також виступає як один 3 найважливіших чинників соціальної мобільності. Суспільство дуже часто не встигає реформувати та вдосконалювати дію соціальних інститутів, адаптовувати їх до нових викликів та потреб, що призводить до послаблення їхньої ролі в контексті покладених на них завдань.

Поглибленню інституційної кризи в суспільстві сприяють також складні світові трансформаційні процеси, що заторкують Україну. Нездатність інституційної гілки держави стабілізувати суспільне життя вимагає від суспільства нагального їхнього переосмислення та реформування. Для сучасного українського суспільства одним з першочергових завдань має бути створення відповідних умов для повноцінного та гармонійного виховання й розвитку молодого покоління. 


\section{СПИСОК ЛІТЕРАТУРИ}

Андрущенко, В. (2011). Основні характеристики європейської університетської освіти та можливості їх реалізації. Філософія і методологія розвитку вищої освіти $У_{\kappa-}$ раїни в контексті європейських процесів. Київ : Педагогічна думка.

Бєлєнька, Г. Богініч, О. Машовець, М. (2006). Здоров'я дитини від родини. Київ : СПД Богданова А. M.

Вишневський, О. (2006). Теоретичні основи сучасної української педагогіки. Дрогобич : Коло.

Горбач, Н. (2006). Філософські переконання Івана Франка. Львів : Каменяр.

Дзеверін, О. (1960). Педагогічні погляди I. Я. Франка. Київ : Радянська школа.

Дорошенко, Н. (1953). Проблема праці в естетиці І. Я. Франка. Львів.

Надольний, I. (2011). Аналіз лідерських компонентів структурної ієрархії керівників підрозділів у вищій школі. Філософія і методологія розвитку вищої освіти України в контексті європейських прочесів. Київ : Педагогічна думка.

Пащук, А. (2007). Філософський світогляд Івана Франка. Львів : Видавничий центр ЛНУ імені Івана Франка.

Скотна, Н. (2005). Особа в розколотій цивілізації : освіта, світогляд, дії. Львів : Українські технології.

Франко, I. (1978). Борис Граб. Зібрання творів у 50 т. (Т. 18). Київ : Наукова думка.

Франко, I. (1978). Захар Беркут. Зібрання творів у 50 т. (Т. 16). Київ
: Наукова думка.

Франко, I. (1986). Лукіан і його епоха. Зібрання творів у $50 \mathrm{~m}$. (T. 45). Київ : Наукова думка.

Франко, І. (1978). Малий Мирон. Зібрання творів у 50 m. (Т. 15). Київ : Наукова думка.

Франко, І. (1978). Наука і її взаємини 3 працюючими класами. Зібрання творів у 50 m. (Т. 45). Київ : Наукова думка.

Франко, I. (1979). Перехресні стежки. Зібрання творів у $50 \mathrm{~m}$. (Т. 20). Київ : Наукова думка.

Франко, I. (1986). Програма галицььких соціалістів. Зібрання mворів у 50 m. (Т. 45). Київ : Наукова думка.

Франко, I. (1979). У кузні. Зібрання творів у 50 m. (Т. 21). Київ : Наукова думка.

\section{REFERENCES}

Andrushhenko, V. (2011). Osnovni kharakterystyky jevropejsjkoji universytetsjkoji osvity ta mozhlyvosti jikh realizaciji. Filosofija i metodologhija rozvytku vyshhoji osvity Ukrajiny v konteksti jevropejsjkykh procesiv. Kyjiv : Pedaghoghichna dumka.

Bjeljenjka, Gh. Boghinich, O. Mashovecj, M. (2006). Zdorov'ja dytyny - vid rodyny. Kyiv : SPD Boghdanova A. M.

Vyshnevsjkyj, O. (2006). Teoretychni osnovy suchasnoji ukrajinsjkoji pedaghoghiky. Droghobych : Kolo.

Ghorbach, N. (2006). Filosofsjki perekonannja Ivana Franka Ljviv : Kamenjar.

Dzeverin, O. (1960). Pedaghoghichni poghljady I. Ja. Franka. Kyiv : Radjansjka shkola.
Doroshenko, N. (1953). Problema praci v estetyci I. Ja. Franka. Ljviv.

Nadoljnyj, I. (2011). Analiz lidersjkykh komponentiv strukturnoji ijerarkhiji kerivnykiv pidrozdiliv u vyshhij shkoli. Filosofija i metodologhija rozvytku vyshhoji osvity Ukrajiny $v$ konteksti jevropejsjkykh procesiv. Kyiv : Pedaghoghichna dumka.

Pashhuk, A. (2007). Filosofsjkyj svitoghljad Ivana Franka. Ljviv : Vydavnychyj centr LNU imeni Ivana Franka.

Skotna, N. (2005). Osoba V rozkolotij cyvilizaciji : osvita, svitoghljad, diji. Ljviv : Ukrajinsjki tekhnologhiji.

Franko, I. (1978). Borys Ghrab. Zibrannja tvoriv u 50 t. (T. 18). Kyiv : Naukova dumka.

Franko, I. (1978). Zakhar Berkut. Zibrannja tvoriv u 50 t. (T. 16). Kyiv : Naukova dumka.

Franko, I. (1986). Lukian i jogho epokha. Zibrannja tvoriv u 50 t. (T. 45). Kyiv : Naukova dumka.

Franko, I. (1978). Malyj Myron. Zibrannja tvoriv u 50 t. (T. 15). Kyiv : Naukova dumka.

Franko, I. (1978). Nauka i jiji vzajemyny z pracjujuchymy klasamy. Zibrannja tvoriv u 50 t. (T. 45). Kyiv: Naukova dumka.

Franko, I. (1979). Perekhresni stezhky. Zibrannja tvoriv u $50 t$. (T. 20). Kyiv : Naukova dumka.

Franko, I. (1986). Proghrama ghalycjkykh socialistiv. Zibrannja tvoriv u 50 t. (T. 45). Kyiv : Naukova dumka.

Franko, I. (1979). U kuzni. Zibrannja tvoriv u 50 t. (T. 21). Kyiv : Naukova dumka.

Стаття надійшла 22.03.2020 p. 